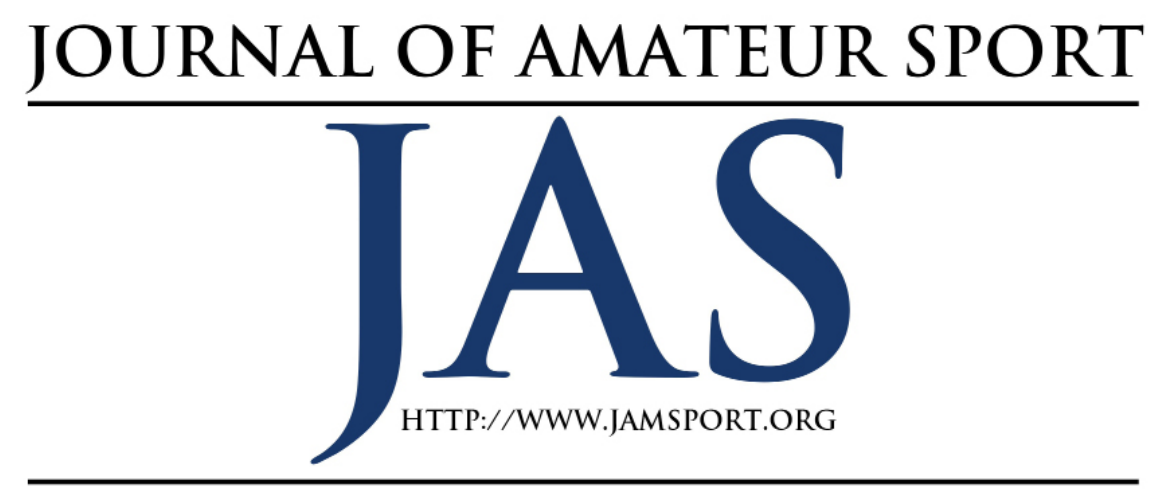

\title{
Manifestations of Athletic Identity in Black Male Collegiate Student-Athletes: Introduction of a Model
}

\author{
Jonathan Howe
}

\section{Ohio State University}

\begin{abstract}
The socialization of Black males into athletics leads to a heightened attention placed on their athletic identity. Once these student-athletes enter the collegiate environment, the institutions of higher education and associated athletic departments have neglected to holistically develop identity within Black male student-athletes. With this population representing less than $3 \%$ of the entire student-body population on college campuses (Harper, 2018), the support that they receive also does not help to counter the negative experiences that they have. Negative experiences then lead to negative outcomes such as becoming susceptible to stereotype threat and identity foreclosure. This paper presents a conceptual model to center race while connecting athletic identity within Black male student-athletes to their experiences on campus and the outcomes related to this identity.
\end{abstract}

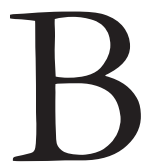
lack males are underrepresented on college campuses, yet Black male student-athletes are overrepresented in sports such as football and basketball (Harper, 2018; National Collegiate Athletic Association [NCAA], 2020b). Examining the Power 5 conferences in the NCAA, Black men represent $55 \%$ and $56 \%$ of football and basketball teams respectively; however, represent less than $3 \%$ of the total student body at these 65 institutions (Harper, 2018). These numbers highlight the value of the Black male to major universities across the U.S. as they face numerous systemic injustices, such as racism and stereotyping (Beamon, 2014; Edwards, 1984; Griffin, 2017), being exploited for their athletic prowess (Cooper, 2019; Hawkins, 2010; Singer, 2019), academic exploitation through course and major selection (Fountain \& Finley, 2009; Sanders \& 
Hildenbrand, 2010), and graduating at lower rates than their white counterparts and Black non-athlete students (Harper, 2018; Singer, 2019; Van Rheenen, 2013). Harper (2018) posited, "Perhaps more outrage and calls for accountability would ensue if there were greater awareness of the actual extent to which college sports persistently disadvantage Black male student-athletes" (p. 2).

Although Black male and female student-athletes are in a "collective struggle” (Singer, 2019, p. 10), Black females face gendered experiences that differ from their male counterparts $(K$. M. Foster, 2003; Simien et al., 2019). Scholars examining Black studentathletes must account for these nuances. However, for the purposes of this paper, the focus is on the relationship between athletic identity and Black male studentathletes at the Division I level.

Athletic identity, as defined by Brewer et al. (1993), is the extent to which an individual identifies with their athletic role. Black athletes have continuously been socialized into prioritizing their athletic role from multiple avenues, such as family, media, and peers (Bimper \& Harrison, 2011; L. Harrison et al., 2017). The impact of athletic identity in Black student-athletes, however, is varied. For example, Black student-athletes have reported financial, social, and psychosocial benefits of being an athlete (Armstrong \& Jennings, 2018; Henry \& Closson, 2012; Singer, 2008). Additionally, there are detriments to identifying with the athletic role, such as being ill-prepared for life after sport (Beamon, 2008, 2012) and negative academic outcomes (Fuller et al., 2017; Stone et al., 2012).

While athletic identity is only one of multiple salient identities within this population, there exists a need to critically examine the impact of athletic identity on the experiences of Black male students. Frameworks exist, such as the Excellence Beyond Athletics (EBA) approach (Cooper, 2016), the Model for College Student-Athlete Academic Success (Comeaux \& Harrison, 2011), and the Anti-Deficit Achievement framework (Harper, 2012), all of which are discussed with more depth in subsequent sections. Each of these frameworks addresses critical needs in the study of Black males and student-athletes, such as holistic development practices (Cooper, 2016), student-athlete academic success (Comeaux \& Harrison, 2011), and Black male academic success (Harper, 2012). However, there remains a need to understand the experiences of Black male college students based on their athletic identity. The purpose of this paper, therefore, is to introduce a framework to critically examine the experiences of Black male Division I student-athletes on college campuses in relation to their athletic identity salience. This paper begins with a discussion of frameworks that guided the conceptualization of the model, followed by an explication of the model. 


\section{Guiding Frameworks}

The proposed model to examine the experiences of Black male studentathletes in relation to their athletic identity was conceptualized after engaging in literature within student development as well as pertinent literature surrounding Black male student-athletes. Likewise, a critical epistemological approach shaped the construction of the model. The frameworks that influenced the proposed model are detailed below.

\section{Critical Race Theory}

The overarching concern with race was influenced by critical race theory (CRT). Utilization of CRT has been a necessary and useful tool within the study of Black athletes (Cooper, 2016; Hodge, Burden, et al., 2008; Simiyu, 2012; Singer, 2005, 2019). This framework enables scholars to center race while seeking to expose and dismantle power structures that perpetuate inequity.

Critical race frameworks are guided by the notion that race and racism are endemic in US society to the point where it becomes ordinary (Bell, 1995; Delgado \& Stefancic, 2017). Understanding the permanence of racism allows scholars the opportunity to center and expose racism in predominantly white collegiate athletic environments and universities. CRT also holds that those who are of the majority and in dominant positions will not act in the interests of minorities unless it is done out of self-interest, which is known as interest convergence (Bell, 1980; Delgado \& Stefancic, 2017; Donnor, 2005). Recognition of interest convergence assists in exposing varying types of exploitation that occur as a result of whites holding the majority of decision-making positions in athletics.

Another tenet of this framework is intersectionality, which is the understanding that minorities often face discrimination and oppression due to marginalized social identities, and the distinction of which identity is the root cause is difficult to make (Collins, 2015; Crenshaw, 1989; Delgado $\&$ Stefancic, 2017). Intersectionality is important when discussing Black male student-athletes as they hold multiple social identities, of which they are discriminated against (Rubin \& Rosser, 2014). Differential racialization is the next tenet, highlighting "the ways that the dominant society racializes different minority groups at different times" based on need (Delgado \& Stefancic, 2017, p. 10). Relating somewhat to exploitation, this tenet could help underscore reasons why institutions treat Black studentathletes differently in varied contexts. The final tenet emphasizes the unique voice of color, noting that being a minority "brings with it a presumed competence to speak about race and racism" (Delgado \& Stefancic, 2017, p. 11). Highlighting the voices of Black male student-athletes helps in countering dominant narratives that are underlying factors in the perpetuation of injustice. 


\section{A Conceptual Model of College Athlete Academic Success}

Comeaux and Harrison (2011) introduced a model to examine the academic success of student-athletes at the collegiate level, which was based on the theory of student attrition and departure by Tinto (1993). The model introduced by Tinto (1993) included six phases: pre-college attributes (educational experiences, family background), precollege/initial goals and commitments, institutional experiences, college integration, post-college goals and commitments, and outcome. The model presented by Comeaux and Harrison (2011) represents the similar aspects that are presented in four stages (pre-college, initial commitments, social system, and commitments), with an inclusion of academic success as opposed to departure. Within the commitment stages, Comeaux and Harrison (2011) included goal, sport, and institutional commitments, which highlights the extent to which student-athletes engage with each of these aspects and helps to identify behaviors of student-athletes. The social system represents college environmental factors, such as faculty interactions, grade performance, and sport participation demands. The manner in which student-athletes respond to ongoing social and academic encounters is essential to their academic success (Comeaux \& Harrison, 2011).

The model introduced by Comeaux and Harrison (2011) has been utilized to analyze the educational experiences of student-athletes in varying contexts, such as those who received a degree in science, technology, engineering, and mathematics (STEM). For example, Comeaux et al. (2017) found that an early understanding of career goals and purposeful involvement in STEM activities prior to entering college contributed to them obtaining their degrees. Aspects of this model can be adapted to focus specifically on the experiences of Black male studentathletes.

\section{Anti-Deficit Achievement Framework}

Initially introduced by Harper (2010) to examine college students of color and their persistence through the STEM pipeline, Harper (2012) narrowed the focus of the framework to examine Black males, not exclusive to particular majors. The framework provides an avenue to understand the success of Black males in college by focusing on three aspects: pre-college socialization and readiness, college achievement, and post-college success (Harper, 2012), which is similar to Tinto's (1993) theory on student attrition and departure as previously discussed. Pre-college factors include family, primary and secondary schooling experiences, and out-ofschool experiences (Harper, 2010). Within this segment, aspects such as parental influence on education, K-12 teacher involvement, and having access to information about college contribute to the success of the Black male. College achievement includes classroom 
experiences, out-of-class engagement, and enriching educational experiences (Harper, 2012). Topics that could be addressed within this segment include relationships cultivated with faculty, academic performance, and utilization of campus resources. Post-college success focuses on graduate school enrollment and career readiness (Harper, 2012). Thus, this segment can help assess whether Black male students are prepared for graduate school or to enter the workforce successfully.

Applying an anti-deficit approach to examining the educational experiences of Black male student-athletes can help scholars focus on the positive influences that lead to their successful matriculation through college. For example, Cooper and Hawkins (2016) applied this framework to examine Black male student-athletes at a historically Black college/university (HBCU). Key findings in this study illustrated that the campus environment (e.g., sense of care and family-like atmosphere) led to the success of these students. By focusing on positive aspects of educational experiences, scholars can use this framework to also counter pejorative dominant ideologies about Black male student-athletes.

\section{Excellence Beyond Athletics}

Excellence Beyond Athletics (EBA) is an approach introduced by Cooper (2016) to improve the educational experiences for Black male studentathletes. This approach takes an anti-deficit perspective to empower this population (Cooper, 2016). The approach was influenced by various existing frameworks, including Comeaux and Harrison's (2011) conceptual model, Tinto's (1993) theory of student departure, CRT, and strategic responsiveness to interest convergence (SRIC; Cooper \& Cooper, 2015). EBA consists of six holistic developmental principles: self-identity awareness, positive social engagement, active mentorship, academic achievement, career aspirations, and balanced time management.

Self-identity awareness repositions a dominant focus on athletic identity to a better understanding of self within Black male student-athletes (Cooper, 2016). The next principle, positive social engagement, "involves the establishment and maintenance of healthy interpersonal relationships within a given social context" (Cooper, 2016, p. 274). This is accomplished through positive interactions within the broader campus society, engagement in educationally rich activities and community service. Building on previous research (Comeaux, 2010a; Kelly \& Dixon, 2014), active mentorship involves formalizing faculty-student mentoring programs, expectations for coaches to work as mentors, and collectives to provide support in various areas of the studentathletes' lives (Cooper, 2016). Academic achievement focuses on the educational environments of the Black male studentathletes. Cooper (2016) discussed 
recommendations, such as collaboration

between athletic departments and university-wide academic support networks; increasing cultural competency from faculty, coaches, and athletic staff who work with these student-athletes; and adjusting the first-year experiences of student-athletes so that there is a heightened focus on academics as opposed to athletic competition.

The final two principles of the EBA approach are career aspirations and balanced time management. Career aspirations involve increasing the opportunities for career exploration outside of sport for Black male studentathletes, which can come through a collaboration of on-campus resources (e.g., career services office, academic advisors, and alumni relations) and offcampus organizations (Cooper, 2016). Additionally, Cooper (2016) called for Black male student-athletes to have the opportunity to freely choose their academic majors without the pressure from athletic departments. Lastly, balanced time management places attention on increasing the time spent on academic and social integration for this population (Cooper, 2016). Thus, Black male student-athletes would be given more autonomy regarding their schedules.

\section{Significance of Introducing a New Model}

The frameworks, mentioned above, served as guiding perspectives for the model conceptualization below. Current models (Comeaux \& Harrison, 2011; Cooper, 2016; Harper, 2012) focus on the academic success and educational experiences of Black males and student-athletes, which are important and necessary approaches. Thus, incorporating aspects of each framework into the proposed model is essential to enhance our understandings of the Black male student-athlete experience.

The model presented in this paper is not intended to negate these frameworks. Instead, it is introduced with a focus on athletic identity and how this aspect of identity within Black male studentathletes impacts other identities and their collegiate experience. Introducing this perspective to examine Black male student-athletes can empower these students to take control of their development while also enabling institutions to assess their role in the development of this population.

\section{Conceptual Model: Manifestations of Athletic Identity in Black Males}

This article introduces a conceptual model to be explicitly applied to Black male student-athletes at the Division I level. Building on the frameworks highlighted above, the Manifestations of Athletic Identity in Black Males (MAIBM) model, highlighted in Figure 1 , centers race in the discussion of Black male student-athletes' pre-college factors, athletic identity influence, athletic identity and the collegiate environment that these student-athletes enter and operate under, and lastly the outcomes of holding this 


\section{Proposition 1 - Race}

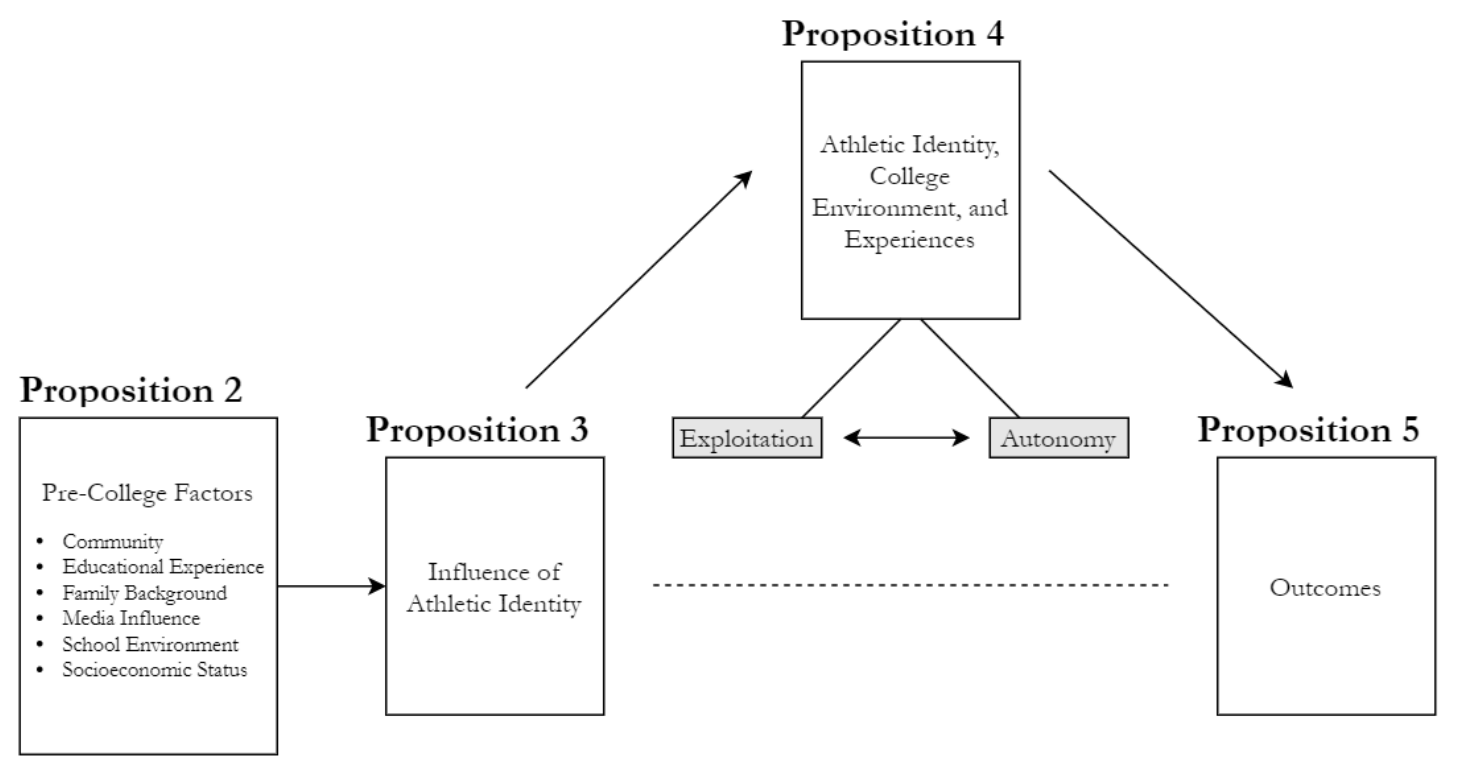

Figure 1. Manifestations of Athletic Identity in Black Males

athletic identity and existing within the college environmental contexts. Each aspect of the framework is highlighted below, beginning with a proposition and concluding with a discussion of literature related to each aspect.

\section{Race}

Proposition 1: The permanence of race leads to racialized experiences of Black male student-athletes that reflect broader U.S. racial subjugations.

Although all student-athletes experience some change and challenges during their time in the college setting, all experiences are not the same. When discussing the Black male student-athlete, it is tough to separate race from their experience (Cooper et al., 2019). This population experiences discrimination on the basis of their racial identity in two aspects - as a Black student on a college campus (Harper, 2009; Harper \& Nichols, 2008) and as a Black male student-athlete (Beamon, 2014; Bimper, 2015; Edwards, 1984).

Discrimination as a Black student is dominant primarily within the context of predominantly white institutions of higher education (PWIHEs; Cooper \& Cooper, 2015; Harper, 2013). Black students on these campuses are stereotyped to be a homogenous group (Harper \& Nichols, 2008); therefore, negative associations are placed on an entire population based on assumptions. 
This is a process that Harper (2009, 2013) described as "niggering," which is a "repetitive activity through which Black women and men are constantly reminded of their long-standing subordinate standing in the U.S. economy, political systems, and myriad social structures (including schools and colleges)" (Harper, 2013, p. 191). Racist stereotypes perpetuated by dominant parties throughout campus and media outlets become so pervasive that they also influence Black males to hold these stereotypes about other Black male peers (Harper \& Nichols, 2008).

Relevant to the discussion of race and Black male student-athletes is the understanding of Black males' late introduction to Division I sports, which was influenced by historical racism and segregation within U.S. society. Schools in the north began integrating sports in the late 1890s (Demas, 2007); however, it was not until white football coaches in the south saw the benefit of having Black players on their teams that they reluctantly integrated their programs between the 1950s and 1970s (Barra, 2013; Kelly, 2009). The effects of historical exclusion remain today as integration was more of an act of interest convergence as opposed to altruism. Since prejudicial attitudes about Black people did not significantly change, discrimination persisted. Today, Black male student-athletes face discrimination not only as students but face challenges from also existing as males and athletes.
The intersection of race and masculinity play into the experiences of Black athletes. As Hawkins (2010) described, the imagery of the Black "brute" characterizes Black males by their physical strength, rendering them "all brawn and no brains" (p. 65). Black male student-athletes have long battled against assumptions and false claims that they are physically superior to white athletes (Sailes, 1993, 2002) as well as intellectual inferiority (Edwards, 1984; Harper, 2018; Sailes, 2002). As discussed in subsequent sections, these assumptions lead to challenging environments for Black male studentathletes.

Existing as a student-athlete does not eliminate Black males from discrimination that is prevalent within the broader U.S. society. Instead, this population, unfortunately, experiences instances of intersectionality where the identity that Black male studentathletes are discriminated against becomes difficult to identify. Thus, within the model, race is represented by the overarching box, indicating the permanence of the construct and influence on every aspect of the studentathletes' lives.

\section{Pre-College Factors}

Proposition 2: Varying degrees of socialization into athletic identity begin before Black male student-athletes enter the college environment, which influences the development of other social identities. 
Black males become socialized into believing that sport is the avenue that they should pursue from an early age (Beamon, 2012; L. Harrison et al., 2017). Young Black men are influenced by the messages portrayed by community members, family, and media, as well as socioeconomic status. Communities reinforce the investment into athletic identity within young Black males by pushing the narrative that prolonged sport careers and exceptional financial rewards are reality (Beamon $\&$ Bell, 2011).

Community influence is also inclusive of their school environment. Attending high schools that have a history of developing elite-level athletes places pressure on Black males to excel athletically (Beamon, 2010). Likewise, schooling experiences impact the focus on sport over a balanced focus on academics, which can lead to academic consequences before these athletes enter the college setting. Zeiser (2011) found Black high school football studentathletes experienced a negative impact on their GPA compared to no effect for their white counterparts. Results also differ per sport as high-profile sports (i.e., revenue-generating sports at the collegiate level) are more detrimental to Black male student-athletes as opposed to their white counterparts (Zeiser, 2011). Some secondary schools maintain cultures that limit the academic expectations for Black male studentathletes, which contributes to a lack of attention in this aspect of their lives (Benson, 2000; Singer, 2016).

Family also influences the amount of focus that Black males place on athletic identity. Beamon (2010) noted, "family, including parents and siblings, is the earliest and most influential socializing agent into sports participation" (p. 287). This influence from family could emphasize placing athletic pursuits over educational attainment (L. Harrison et al., 2017). On the contrary, family can also encourage academic success. Although not exclusive to Black male studentathletes, Comeaux et al. (2017) found that student-athletes who completed their degrees in STEM fields had high educational aspirations that were pushed on them by their family from early ages. These findings extend to Black studentathletes, as Harris et al. (2015) discussed high school Black male athletes excelling in academic and athletic pursuits due to the values instilled in them by their parents and siblings. Thus, family can either influence a singular focus on sport by emphasizing the importance of investing heavily into athletic identity or guide Black male student-athletes into a more holistic approach by highlighting the value of education and developing identities outside of sport at an early age.

Media portrayals sensationalize the lives of Black male professional football and basketball players while limiting the exposure of successful Black men in other industries (L. Harrison et al., 2002). Similar to representation in 
college sports, Black males represent roughly $75 \%$ and $60 \%$ of the National Football League and National Basketball Association athletes, respectively (Lapchick, 2019a, 2019b). With majority representation in these sports at both college and professional ranks, young Black boys see themselves within these athletes and equate success with reaching the professional status, reinforcing the singular focus on sport phenomenon. Regarding socioeconomic status, Black families particularly attracted to football and basketball, find these two sports to be more accessible financially and geographically as they require less of a financial commitment and are also more likely to be offered by the local schools in their neighborhoods (Hodge, Harrison, et al., 2008). The attraction to these sports also lies, in part, to their want to escape their social conditions (Harris, 2014; Singer \& May, 2011). Black youth are influenced by the notion that participation in sport could lead to financial and social rewards that could alleviate economic hardships.

Black male college athletes enter the college environment with predispositions to athletic identity. These predispositions are largely related to athletic identity socialization that limits the exploration and development of other identities and roles within the lives of Black male student-athletes. However, research has also found Black male student-athletes to be in an environment that places value on educational pursuits and exploration of other identities (Harris et al., 2015).
The level of engagement with athletic identity in Black male student-athletes before they enter the collegiate setting will impact their development of other social identities and collegiate educational experience.

\section{Influence of Athletic Identity}

Proposition 3: Black male student-athletes exist within the college setting with an identity as an athlete, which shapes their perceptions of themselves during their time on campus as well as future selves.

With Black male student-athletes entering the college setting to participate in sport, it is reasonable to perceive a substantial salience of athletic identity to be already present. However, the perceptions Black male student-athletes have of themselves may also vary depending on other identities that are salient based on their opportunity to explore other domains of their lives. Within student development, it is commonly understood that individuals are made up of multiple identities that are simultaneously salient (Jones \& McEwen, 2000). Therefore, Black male student-athletes are comprised of their athletic identity, student/academic identity, racial identity, gender, class identity, and sexual orientation, among many others. Jones and McEwen (2000) emphasized the notion that although these identities are simultaneously salient, the level of saliency often differs between contexts. Thus, in one context, a Black male student-athlete could experience their racial identity being 
extremely salient while their athletic identity is less salient (Steinfeldt et al., 2010). With the influence of other contextual factors, Black male studentathletes exist in settings that emphasize a higher saliency of athletic identity than other social identities (Beamon, 2010). Throughout the remaining section relating to Proposition 3, I highlight athletic identity in relation to other aspects of identity and self-perceptions within this population.

\section{Athletic and Racial Identity}

Most literature surrounding Black student-athlete identity argues that athletic and racial identity are positively associated (L. Harrison et al., 2002; Hodge, Burden, et al., 2008). Findings from Brown et al. (2003), however, add an interesting perspective to the relationship between athletic and racial identity. These identities within Black student-athletes in this study had an inverse relationship as a higher perception of race being a central part of their self-image came when athletic identity was lower for the Black studentathlete (Brown et al., 2003). Additionally, when athletic identity was more salient, Black student-athletes were more likely to perceive racial discrimination as no longer a problem in the U.S. (Brown et al., 2003). Thus, in some cases, a heightened sense of athletic identity combined with contextual factors (e.g., racial makeup of coaching staff, teammates, and students) contribute to a racelessness mindset in Black studentathletes (Brown et al., 2003).

Although race is prevalent in U.S. society, athletic identity can push racial identity into the "shadows" of Black male student-athletes' selfconceptualization (Bimper \& Harrison, 2011). Narratives from participants in Singer's (2016) study illustrated the tendency for Black male student-athletes to focus on athletic development as opposed to racial identity development. This sentiment comes as members of this population recognize their time in the collegiate setting as their chance to maximize their athletic identity (Cooper \& Cooper, 2015). However, despite the influence of athletic identity, completely ignoring racial identity can be a challenge for these athletes (Bimper et al., 2013). While L. Harrison et al. (2002) noted that athletic and racial identity were connected, many Black male athletes face discrimination based on their racial identity (Beamon, 2014; Bimper, 2015; Singer, 2016).

Team settings and institutional type can also dictate the saliency of Black student-athlete identities. Clopton (2011) highlighted the impact that team sports have on racial identity, where the scholar found that the team setting mitigated differences of race. However, when student-athletes were in the traditional university setting, this was not the case. Thus, student-athletes often fall into a colorblind mentality, which can create problems stemming from racist practices 
(Bimper, 2015). This colorblind mentality was then lost when the student-athletes entered the university setting; meaning, Black student-athletes experienced an increase in the saliency of their identities. Regarding another contextual factor (institution type), Black student-athletes at PWIHEs indicated a higher salience of athletic identity than Black studentathletes at HBCUs (Steinfeldt et al., 2010). Likewise, players at HBCUs felt a stronger sense of freedom to explore and be proud of racial ideologies that are not often valued at PWIHEs (Steinfeldt et al., 2010).

\section{Athletic and Academic Identity}

Student-athletes, particularly in the collegiate setting, are bound by significant time constraints, with most of their attention being placed on their sport participation (Comeaux \& Harrison, 2011; Hodge, Burden, et al., 2008). This, in turn, impacts the saliency of other identities. Likewise, the context remains a major influence on the salience and development of these identities as well. Lu et al. (2018) found that studentathletes identified more as a student when they attended higher ranking academic institutions, which further highlights the influence of contextual factors on identity.

Despite the popular thought that student-athletes' athletic identity overshadows their academic identity, many student-athletes actually turn to faculty members who serve "the role of intellectual coach"' (C. K. Harrison et al.,
2006, p. 277). Within these interactions between faculty members and studentathletes, academic identity becomes more salient. Speaking specifically for Black student-athletes, those who hold positive racial perceptions have higher academic self-concept (Fuller et al., 2017). However, Black studentathletes are often entering the collegiate academic setting being less prepared academically (Benson, 2000; Donnor, 2005; Hodge, Burden, et al., 2008), which could lead to their student/academic identity being less salient. Likewise, the athletic performance within Black student-athletes directly connects to their perceptions of academic performance (Fuller et al., 2017).

\section{Athletic Identity and Scholarship Status}

Closely related to academic identity are the experiences of Black male student-athletes that can be influenced by their status of holding an athletic scholarship versus participating in sport as a walk-on or a partial scholarship athlete. Research has shown that for the general student-athlete population, scholarship students graduate at faster rates than non-scholarship athletes (Rubin \& Rosser, 2014). However, Black male scholarship student-athletes graduate at slower rates than their white counterparts (Harper, 2018; Rubin, 2016). Additionally, Black male scholarship student-athletes have acknowledged their position within the athletic department kin to an 
employee in an organization focused on athletic success (Cooper \& Cooper, 2015). Since athletic scholarships are not based on academic merit and Black male scholarship athletes take longer to graduate (Rubin, 2016), Black male scholarship athletes may perceive an increased obligation to focus on their athletic pursuits than non-scholarship athletes.

\section{Athletic Identity and Career Maturity}

Similar to other identities, the time focused on athletic identity causes athletes to neglect development in other areas within the student-athlete. While not specific to Black male studentathletes, various studies have found there to be an inverse relationship between athletic identity and career maturity (Houle \& Kluck, 2015; Murdock et al., 2016). Houle and Kluck (2015) found that "more strongly identifying with the athletic role and lower levels of career decision-making self-efficacy were independently associated with lower levels of career maturity among collegiate student-athletes" (p. 34). In relation to non-student-athletes, career maturity within student-athletes tended to be lower than non-athletes (Murdock et al., 2016). Regarding the Black student-athlete, career perceptions are largely influenced by pre-college factors that narrow the focus on professional sports (L. Harrison et al., 2017, 2002). This narrowed focus leads to a minimized perception of career or postundergraduate educational possibilities.

\section{Athletic Identity, College} Environment, and Experiences Proposition 4: Athletic identity and participation in sport directly influence the experiences of Black male student-athletes while on campus.

Characteristics of students who are involved on college campuses are likely to change from the time they enter the setting and leave this environment (Astin, 1984). An influential factor in determining an individual's athletic identity comes from their participation in sport. Specifically, at the collegiate level, simply self-identifying or being perceived as a student-athlete can have mixed implications. The identity of studentathletes is described as being a "doubleedged sword" as simply embracing that identity has benefits as well as consequences for these individuals (Melendez, 2009, p. 349).

\section{Negative Experiences}

Existing as a student-athlete on a college campus, regardless of how much that identity is portrayed, creates varying perceptions from faculty members and the campus community at large. Participation in sport at the collegiate level also leads to microaggressions from the campus community, which is particularly true for minority studentathletes (Comeaux, 2012; Simons et al., 2007). These microaggressions often arise in questioning the student-athlete's intelligence as well as their academic motivation, which can have a profound effect on the well-being of the student- 
athlete (Comeaux, 2012). It becomes difficult for Black male student-athletes to conceal the physical traits (e.g., stature) and other identifiers, such as attire (e.g., team-issued clothing) that are associated with their athletic identity (Armstrong \& Jennings, 2018; Oseguera, 2010; Wininger \& White, 2015). Therefore, athletic identity within Black male student-athletes often persists regardless of intent, making them susceptible to negative associations such as the being the Black dumb jock (Edwards, 1984; L. Harrison et al., 2011; Sailes, 1993).

Similar to the impact of pre-college participation in sports on academic performance (Zeiser, 2011), these effects persist within Black male college student-athletes whereby this population continues to graduate at rates lower than their white counterparts (Harper, 2018; NCAA, 2020a). Higher levels of athletic identity lead to lower GPA scores for Black males participating in sport (Bimper, 2014). This unfortunate reality is a result of the lack of emphasis placed on the academic development of Black male student-athletes from the athletic department and academic institutions broadly (Bimper, 2014; Bimper \& Harrison, 2011). Stereotypes regarding academic performance prevail throughout the institution, whereby faculty have lower academic expectations for this population (Comeaux, 2010b). Additionally, because of these perceptions, faculty and students alike become surprised when Black male student-athletes exude academic excellence (Bimper et al., 2013; Simons et al., 2007). Coping with this athletic stigma causes student-athletes to attempt to hide their athletic identity from their professors, which can cause problems when the student-athletes need accommodations for missing class due to competition (Simons et al., 2007).

Stereotypes and prejudicial views can create a hostile college environment for Black male student-athletes (Beamon, 2014; Cooper, 2016; Melendez, 2008). In addition to the academic stereotypes mentioned above, Black male athletes have expressed experiencing racism while on campus. For example, Singer (2005) highlighted the voices of Black football players who dealt with differential treatment relating to scheduling classes and discipline in relation to their white teammates. Black male athletes are also on the receiving end of racist statements that are made throughout campus (Beamon, 2014). Thus, existing within a hostile PWIHE environment can create negative experiences for student-athletes in this population.

\section{Positive Experiences}

On the positive side, participation in athletics increases the bond between student-athletes and their institution as student-athletes have reported higher attachment to their university than non-student-athletes (Melendez, 2006). Athletic participation has also been attributed to assisting in easing the sense of loneliness and with social adjustment of student-athletes (Clopton, 2011; 
Miller \& Kerr, 2003). Likewise, Cooper and Cooper (2015) noted that for Black male student-athletes, sport participation offers an environment kin to a safe haven that allows the athletes to receive positive affirmations. The saliency of athletic identity impacts student-athletes in numerous ways, such that they are able to find community and a sense of belonging as well as having to experience environments that are ridden with negative associations.

For some Black male studentathletes, athletic identity has also served as a buffer to deal with racism and the stigmas associated with their academic identity. Their high-profile status creates an understanding of self that protects them from racism that nonathlete Black students may experience at PWIHEs (Henry \& Closson, 2012). With increased awareness, identity as an athlete also creates social capital that allows Black males to interact in predominantly white spaces and have relationships with people outside of their race (Armstrong \& Jennings, 2018; Bimper, 2016). Additionally, developmental programs explicitly designed for Black student-athletes have been found to increase the positive experiences through empowerment and helping this population understand how to navigate predominantly white spaces (Bimper, 2017; Cooper et al., 2019). Empowerment also protects Black male student-athletes from the exploitation that occurs within college athletics.

\section{Exploitation versus Autonomy}

Within Proposition 4, a continuum exists between exploitation and autonomy of Black male studentathletes. Scholars have highlighted the numerous ways in which institutions exploit Black male student-athletes for the athletic talent (Cooper, 2019; Donnor, 2005; Hawkins, 2010). Thus, in these situations, Black male studentathletes are often controlled by athletic departments regarding how they spend their time. Most of this time is spent on sport-related activities, which inhibits these student-athletes from taking advantage of their college education and experience (Singer, 2008). Therefore, the development of Black male studentathletes may be limited to athletics while not experiencing much development in other areas of their lives.

Within the EBA approach, Cooper (2016) called for Black male athletes to have the opportunity to have more autonomy regarding their schedules and time spent focused on athletic participation. By freeing the athlete of these constraints, they will be able to develop identities and roles outside of sport, which could positively impact their college experience. Indicated by the work of Cooper et al. (2019), some institutions have moved to increase the autonomy of Black male student-athletes. Thus, the continuum exists to illustrate the level autonomy given to this population and how that could impact the development of other identities as well as the college 
experiences of Black male studentathletes.

Overall, in the context of big-time collegiate sport, an emphasis on athletic success creates an environment that deters the holistic development of the Black male student-athlete (Cooper, 2016, 2019; Lanter \& Hawkins, 2013). Additionally, the willingness of faculty members on campuses to interact with Black student-athletes and not "other" them plays an instrumental role in their outcomes (Comeaux \& Harrison, 2007; C. K. Harrison et al., 2006). Thus, the college environment and characteristics impact Black student-athletes' identity development and attitudes toward the university, which will likely impact their outcomes. All colleges and athletic departments do not exist as monoliths; therefore, the amount of resources an institution dedicates to the holistic development of the Black student-athlete will determine some of the outcomes.

\section{Outcomes}

Proposition 5: The heightened saliency of athletic identity leads to outcomes that are detrimental to the development of Black male student-athletes.

Athletic identity impacts many outcomes within student-athletes. Some of those outcomes are within their identity development, academic performance, and choice of major/ discipline. A substantial amount of focus toward the athletic identity is due to the neoliberal capitalism that is prevalent in the collegiate athletic model, which often presents consequences for the student-athletes (Gaston-Gayles et al., 2018). Likewise, with stereotypes surrounding the student-athletes, their mere association with athletic identity impacts outcomes as previously noted. Although many outcomes are related to Proposition 4, there may be instances where these factors do not heavily influence outcomes. A dotted line between Proposition 3 and 5 signifies this potential relationship when college environmental factors are not significant influencers. This section discusses stereotype threat, identity foreclosure, as well as educational implications related to athletic identity.

\section{Stereotype Threat}

Steele and Aronson (1995) defined stereotype threat as "being at risk of confirming, as self-characteristic, a negative stereotype about one's group" (p. 797). As existing research proves, student-athletes face negative stereotypes about their academic abilities (Edwards, 1984; Simons et al., 2007; Wininger \& White, 2015). Therefore, simply having an athletic identity brings forth associated negative stereotypes. Higher profiled sports (i.e., football and basketball), as well as higher levels of competition, carry an increased occurrence of stereotype threat (Feltz et al., 2013). Studies examining stereotype threat have illustrated the negative impact that athletic identity has on educational outcomes within student-athletes at the collegiate level 
(Griffin, 2017; Stone et al., 2012). The dumb jock stigma associated with student-athletes contributes to academic underperformance (Fuller, 2017; Stone et al., 2012).

Race is also an essential factor when examining this phenomenon. Stone et al. (2012) argued that Black studentathletes who are academically engaged are most susceptible to stereotype threat when their scholar and athletic statuses are linked. Likewise, Black studentathletes are more susceptible to this threat than their white colleagues who "may be somewhat immune to cues that activate their identity as an athlete in the classroom" (p. 101). Black male student-athletes also recognize that they are stereotyped for more than simply their athletic identity and react to these stereotypes in different manners. For example, in effort to not be categorized as the "angry Black kid," some Black male student-athletes rarely voiced their thoughts while in class (Griffin, 2017). Thus, Black male student-athletes confront stereotypes of being an athlete as well as identifying as Black.

Negative stereotypes associated with student-athletes are among numerous reasons as to why stereotype threat exists. Another factor that can contribute to a student-athlete experiencing adverse outcomes is their relationships with their coaches. For example, coaches play an influential role in the impact of stereotype threat within their studentathletes as they often highlight athletic abilities, but less often show belief in their student-athletes' academic ability (Feltz et al., 2013). This result comes as coach interaction often impacts student-athletes' level of athletic identity, whereby neglect from coaches to highlight their student-athletes' student identity causes them to focus more on their athletic identity (Feltz et al., 2013).

\section{Identity Foreclosure}

One of the most influential developmental aspects of studentathlete identity is the opportunity to explore multiple social identities. Conflict occurs within these identities as they can be contradictory to one another (Killeya-Jones, 2005). There are two ways to handle this conflict, find a balance between those identities (Killeya-Jones, 2005) or experience identity foreclosure (Beamon, 2012). Foreclosure can occur within various social identities; however, athletic identity foreclosure has been defined as "commitment to the athlete role in the absence of exploration of occupational or ideological alternatives" (Brewer \& Petitpas, 2017, p. 118). The increased commercialization of college sport along with the rise in coaching salaries and incentives for winning intensifies athletic identity foreclosure, which negatively impacts the development of Black male student-athletes (Cooper, 2016; Porter, 2019). This environment influences these student-athletes before they enter college, during their time on campus, and after their sport careers have ended (Beamon, 2012). The nature 
of college sports severely constrains student-athletes to focus most of their time to their sport participation, practice, study, and rehabilitation (Beamon, 2012; Cooper \& Cooper, 2015; C. K. Harrison et al., 2006; Parsons, 2013), which limits the time that they have to explore and develop other identities.

Identity foreclosure often occurs more frequently within studentathletes as opposed to their non-athlete counterparts. Beamon (2012) explained that non-athletes have the autonomy to explore various majors, courses, and opportunities that suit their interests. "Student-athletes, on the other hand, have little time or freedom to explore as they operate under strict time and academic eligibility constraints" (p. 197). This serves as a detriment to the student-athlete as an increase in identity foreclosure leads to lower levels of career maturity (Brewer \& Petitpas, 2017).

Identity foreclosure has the potential to be mitigated. Finding a balance between conflicting identities is vital to alleviating student-athletes experiencing foreclosure (Cooper, 2016; KilleyaJones, 2005). When the conflicting roles (i.e., student and athlete) are in harmony, less conflict occurs (KilleyaJones, 2005). However, the businesslike nature of college athletics places an extreme amount of attention to a model that glorifies athletic pursuits over other interests (Gaston-Gayles et al., 2018). Thus, one solution to balancing the identities of student-athletes is to mandate that coaches create more flexibility within their players' schedules (Cooper, 2016; Killeya-Jones, 2005).

\section{Academic Impact}

The extent to which student-athletes identify with their athletic identity impacts their student role, which is particularly true for Black studentathletes. Black male student-athletes have historically been unable to reach graduation rates comparable to their white counterparts (Cooper, 2016). Since Black student-athletes make up the most substantial portions of participants within high profile sports (NCAA, 2020b), this further highlights collegiate athletic departments' and institutions' willingness to place Black male studentathletes' athletic identity above all others. Regarding their academic support services, student-athletes who strongly identify with their student identity are more likely to visit academic services if they had a low GPA as opposed to those who identify more with their athletic role (Antshel et al., 2016). Thus, athletic departments pushing attention on athletic identity impacts the studentathlete, specifically the Black male student-athlete, in a negative manner academically.

An increase in athletic identity is related to higher chances of studentathletes being enrolled in majors that are determined to be less difficult (S. J. L. Foster \& Huml, 2017). This often leads to academic clustering, which is the tendency for members of the same team to enroll in the same major (S. J. L. Foster 
\& Huml, 2017; Sanders \& Hildenbrand, 2010; Schneider et al., 2010). In its purest form (i.e., absent of any coercive methods), academic clustering is not something that should be viewed as unfavorable. However, student-athletes are sometimes strongly advised to declare certain majors from support staff, which becomes problematic. When over $70 \%$ of a team is in a single major (Fountain \& Finley, 2009), questions arise which center around the academic practices of those institutions and athletic departments. Relying solely on your association with athletic identity to determine majors significantly constrains the student-athlete and their future professional options.

\section{Conclusion and Implications}

The MAIBM provides a framework to examine the development of identity and experiences of Black male studentathletes in relation to their athletic identity. Although athletic identity was chosen as the reference identity, it remains a challenge to separate their experiences based solely on one social category. When discussing the development of the Black studentathlete, it is essential also to centralize race. Based on that last statement, a limitation of this model is the lack of explicit inclusion of additional aspects that contribute to the holistic development of a student-athlete such as ethnicity, relationships, and religion, to name a few.
The MAIBM does not seek to eliminate these factors; rather, it centers identities that are considered most salient to Black male student-athletes informed by over three decades of literature related to this population. The model does posit aspects of identity in Proposition 2, such as community, family influences, and socioeconomic status that impact their time on college campuses. However, Black male student-athletes could identify with multiple ethnicities (e.g., African American or Afro-Latino), which could further impact their precollege experiences, such as participation in a specific sport(s), as well as their experiences on a PWIHE. Scholars should refrain from essentializing the "Black" experience and, instead, embrace the ethnic diversity within racial groups (Singer, 2019). Thus, I acknowledge less salient identities could influence the Black male student-athlete experience. Scholars utilizing this framework should be privy to these multiple influences on the experiences of collegiate Black male student-athletes.

The desired overarching outcome of the MAIBM is to improve the holistic experience for Black male studentathletes. In order words, elimination of athletic identity foreclosure, intentional exploration and development of identities outside of their athletic role, increased career maturity, and creation of inclusive campus environments. This model should not only be utilized by scholars; instead, institutions of higher 
education and athletic departments are strongly encouraged to incorporate the MAIBM into their programming services that they offer Black male studentathletes.

The combination of Black male student-athletes' individual characteristics and institutional factors provides an avenue for institutions to directly examine and meet the psychosocial developmental needs of these students. Athletic department personnel would be able to create personalized development plans for each Black male student-athlete, unique to their individual backgrounds and identity development. For example, a student-athlete may come into the college setting with an understanding of their post-athletic career path. That student would have a plan that could connect them with alumni in those industries to allow them to create networks and have potential shadowing or internship opportunities. A studentathlete on the other end of the spectrum may be more focused on their athletic identity development and need more time in career exploration. Therefore, personnel within the athletic department can connect that athlete with the career services department on campus, have them participate in career fairs, and connect the student with academic support services to ensure that they are able to explore a range of academic majors that will fit their career choice.

Athletic departments and institutions can also use the MAIBM to assess their role in the development of Black male student-athletes and implement practices to contribute to a holistic developmental experience. Echoing recommendations from Cooper (2016), the evaluations of coaches and athletic personnel should be revised to emphasize not only academic development but also personal development. Since coaches are the true gatekeepers of their studentathletes' time, placing a similar weight on non-athletic development as athletic performance would redistribute the focus from wins and losses to a more balanced approach. Additionally, implementing these practices would likely free the athletes from unnecessary athletic commitments so that they can engage in other roles within their lives.

Another direct practice that can be drawn from this model is collaboration between the athletic department and institution to eliminate biases and stereotypes associated with Black male student-athletes. This could be solved by allowing Black male student-athletes to be more visible within the broader campus environment as opposed to being seen primarily during athletic performances. Additionally, campaigns directed at increasing the interactions of Black male student-athletes with the general student body and faculty members in academic and non-athletic settings could assist in eliminating associating the student-athlete as solely an athlete, creating a less hostile campus environment.

Numerous athletic departments and colleges boast about holistically 
developing students; however, there is no one size fits all model. It is imperative that these institutions place a deliberate focus on better serving Black male student-athletes. This calls for both Black male student-athletes and athletic departments to acknowledge the influence of athletic identity on the college experience and development of the student-athlete.

\section{References}

Antshel, K. M., Vanderdrift, L. E., \& Pauline, J. S. (2016). The role of athletic identity in the relationship between difficulty thinking or concentrating and academic service use in NCAA student-athletes. Journal of Clinical Sport Psychology, 10(4), 309-323. https://doi.org/10.1123/ jcsp.2015-0028

Armstrong, K. L., \& Jennings, M. A. (2018). Race, sport, and sociocognitive "place" in higher education: Black male student-athletes as critical theorists. Journal of Black Studies, 49(4), 349.

Astin, A. W. (1984). Student involvement: A developmental theory for higher education. Journal of College Student Development, 25(4), 297-208.

Barra, A. (2013, November 15). The integration of college football didn't happen in one game. The Atlantic.

Beamon, K. K. (2008). “Used goods": Former African American college student-athletes' perception of exploitation by Division I universities.
Journal of Negro Education, 77(4), 352364.

Beamon, K. K. (2010). Are sports overemphasized in the socialization process of African American males? A qualitative analysis of former collegiate athletes' perception of sport socialization. Journal of Black Studies, 41(2), 281-300. https://doi. org $/ 10.1177 / 0021934709340873$

Beamon, K. K. (2012). "I'm a baller": Athletic identity foreclosure among African-American former studentathletes. Journal of African American Studies, 16(2), 195-208. https://doi. org/10.1007/s12111-012-9211-8

Beamon, K. K. (2014). Racism and stereotyping on campus: Experiences of African American male studentathletes. Journal of Negro Education, 83(2), 121-134.

Beamon, K. K., \& Bell, P. (2011). A dream deferred: Narratives of African American male former collegiate athletes' transition out of sports and into the occupational sector. Journal for the Study of Sports and Athletes in Education, 5(1), 29-44. https://doi. org/10.1179/ssa.2011.5.1.29

Bell, D. A. (1980). Brown v. Board of Education and the interestconvergence dilemma. Harward Law Review, 93(3), 518-533.

Bell, D. A. (1995). Who's affraid of critical race theory? University of Illinois Law Review, 893-910. https://doi. org/10.1177/0011392109342205

Benson, K. F. (2000). Constructing academic inadequacy: African 
American athletes' stories of schooling. The Journal of Higher

Education, 71(2), 223-246.

Bimper Jr., A. Y. (2014). Game changers: The role athletic identity and racial identity play on academic performance. Journal of College Student Development, 55(8), 805-807. https:// doi.org/10.1353/csd.2014.0078

Bimper Jr., A. Y. (2015). Lifting the veil: Exploring colorblind racism in Black student athlete experiences. Journal of Sport and Social Issues, 39(3), 225-243. https://doi. org/10.1177/0193723513520013

Bimper Jr., A. Y. (2016). Capital matters: Social sustaining capital and the development of Black studentathletes. Journal of Intercollegiate Sport, 9(1), 106-128. https://doi. org/10.1123/jis.2015-0001

Bimper Jr., A. Y. (2017). Mentorship of Black student-athletes at a predominately White American university: critical race theory perspective on student-athlete development. Sport, Education and Society, 22(2), 175-193. https:// doi.or $\mathrm{g} / 10.1080 / 13573322.2015 .1022524$

Bimper Jr., A. Y., \& Harrison Jr., L. (2011). Meet me at the crossroads: African American athletic and racial identity. Quest, 63(3), 275-288.

Bimper Jr., A. Y., Harrison Jr., L., \& Clark, L. D. (2013). Diamonds in the rough: Examining a case of successful Black male student athletes in college sport. Journal of Black Psychology, 39(2), 107.
Brewer, B. W., \& Petitpas, A. J. (2017). Athletic identity foreclosure. Current Opinion in Psychology, 16, 118-122. https://doi.org/10.1016/j. copsyc.2017.05.004

Brewer, B. W., Van Raalte, J. L., \& Linder, D. E. (1993). Athletic identity: Hercules' muscles or Achilles heel? International Journal of Sport Psychology, 24(2), 237-254.

Brown, T. N., Jackson, J. S., Brown, K. T., Sellers, R. M., Keiper, S., \& Manuel, W. J. (2003). "There's no race on the playing field": Perceptions of racial discrimination among white and black athletes. Journal of Sport and Social Issues, 27(2), 162-183. https://doi. org/10.1177/0193732502250715

Clopton, A. W. (2011). Using identities to explore social capital differences among white and African American student athletes. Journal of African American Studies, 15(1), 58-73. https://doi.org/10.1007/s12111-0109121-6

Collins, P. H. (2015). Intersectionality's definitional dilemmas. Annual Review of Sociology, 41, 1-20. https://doi.org/10.1146/annurevsoc-073014-112142

Comeaux, E. (2010a). Mentoring as an intervention strategy. Journal for the Study of Sports and Athletes in Education, 4(3), 257-275. https://doi. org/10.1179/ssa.2010.4.3.257

Comeaux, E. (2010b). Racial differences in faculty perceptions of collegiate student-athletes' academic and post- 
undergraduate achievements. Sociology of Sport Journal, 27(4), 390.

Comeaux, E. (2012). Unmasking athlete microaggressions: Division I studentathletes' engagement with members of the campus community. Journal of Intercollegiate Sport, 5(2), 189-198. https://doi.org/10.1123/jis.5.2.189

Comeaux, E., Bachman, T., Burton, R. M., \& Aliyeva, A. (2017). Undergraduate experiences of Division I athlete science, technology, engineering, and mathematics (STEM) graduates. Journal of Science Education and Technology, 26(1), 24-32. https://doi.org/10.1007/s10956-0169648-y

Comeaux, E., \& Harrison, C. K. (2007). Faculty and male student athletes: Racial differences in the environmental predictors of academic achievement. Race Ethnicity and Education, 10(2), 199-214. https:// doi.org/10.1080/13613320701330726

Comeaux, E., \& Harrison, C. K. (2011). A conceptual model of academic success for studentathletes. Educational Researcher, 40(5), 235-245. https://doi. org/10.3102/0013189X11415260

Cooper, J. N. (2016). Excellence beyond athletics: Best practices for enhancing Black male student athletes' educational experiences and outcomes. Equity and Excellence in Education, 49(3), 267-283. https:// doi.org/10.1080/10665684.2016.119 4097
Cooper, J. N. (2019). From exploitation back to empowerment: Black male holistic (under)development through sport and (mis) education. Peter Lang.

Cooper, J. N., \& Cooper, J. E. (2015). "I'm running so you can be happy and I can keep my scholarship": A comparative study of Black male college athletes' experiences with role conflict. Journal of Intercollegiate Sport, 8(2), 131-152. https://doi. org/10.1123/jis.2014-0120

Cooper, J. N., Corral, M. D., Macaulay, C. D. T., Cooper, M. S., Nwadike, A., \& Mallery, M. (2019). Collective uplift: The impact of a holistic development support program on Black male former college athletes' experiences and outcomes. International Journal of Qualitative Studies in Education (QSE), 32(1), 21-46. https://doi.org/10.1080 /09518398.2018.1522011

Cooper, J. N., \& Hawkins, B. J. (2016). An anti-deficit perspective on black male student athletes' educational experiences at a historically black college/university. Race Ethnicity and Education, 19(5), 950.

Crenshaw, K. W. (1989). Demarginalizing the intersection of race and sex: A Black feminist critique of antidiscrimination doctrine, feminist teory and antiracist politics. The University of Chicago Legal Forum, 1989, 139-168.

Delgado, R., \& Stefancic, J. (2017). Critical race theory: An introduction (3rd ed.). New York University Press. 
Demas, L. (2007). Beyond Jackie Robinson: Racial integration in American college football and new directions in sport history. History Compass, 5(2), 675-690. https://doi.org/10.1111/j.14780542.2007.00412.x

Donnor, J. K. (2005). Towards an interest-convergence in the education of African-American football student athletes in major college sports. Race Ethnicity and Education, 8(1), 45-67. https:/ /doi. org/10.1080/1361332052000340999

Edwards, H. (1984). The Black "dumb jock": An American sports tragedy. College Board Review, 131, 8-13.

Feltz, D. L., Schneider, R., Hwang, S., \& Skogsberg, N. J. (2013). Predictors of collegiate student-athletes' susceptibility to stereotype threat. Journal of College Student Development, 54(2), 184-201. https://doi. org/10.1353/csd.2013.0014

Foster, K. M. (2003). Panopticonics: The control and surveillance of Black female athletes in a collegiate athletic program. Anthropology and Education Quarterly, 34(3), 300-323. https://doi. org/10.1525/aeq.2003.34.3.300

Foster, S. J. L., \& Huml, M. R. (2017). The relationship between athletic identity and academic major chosen by student-athletes. International Journal of Exercise Science, 10(6), 915-925.

Fountain, J. J., \& Finley, P. S. (2009). Academic majors of upperclassmen football players in the Atlantic Coast Conference: An analysis of academic clustering comparing white and minority players. Journal of Issues in Intercollegiate Athletics, 2, 1-13.

Fuller, R. D. (2017). Perception or reality: The relationship between stereotypes, discrimination, and the academic outcomes of African American male college athletes. Journal of Sport and Social Issues, 41(5), 402-424. https:// doi.org/10.1177/0193723517719664

Fuller, R. D., Harrison, C. K., \& Bukstein, S. J. (2017). A study of significance of racial and athletic identification on educational perceptions among African American male college athletes. Race Ethnicity and Education, 20(5), 711-722. https:/ / doi.org/10.1080/13613324.2016.115 0829

Gaston-Gayles, J., Comeaux, E., Ofoegbu, E., \& Grummert, S. (2018). Neoliberal capitalism and racism in college athletics: Critical approaches for supporting student-athletes. New Directions for Student Services, 163, 1121. https://doi.org/10.1002/ss.20266 Griffin, W. (2017). Who is Whistling Vivaldi? How Black football players engage with stereotype threats in college. International Journal of Qualitative Studies in Education, 30(4), 354-369. https://doi.org/10.1080/09 518398.2016.1250174

Harper, S. R. (2009). Niggers no more: A critical race counternarrative on Black male student achievement at predominantly White colleges and universities. International Journal of Qualitative Studies in Education, 
22(6), 697-712. https://doi.

org/10.1080/09518390903333889

Harper, S. R. (2010). An anti-deficit achievement framework for research on students of color in STEM. New Directions for Institutional Research, 2010(148), 63-74. https://doi. org/10.1002/ir.362

Harper, S. R. (2012). Black male student success in higher education: A report from the National Black Male Achievement Study.

Harper, S. R. (2013). Am I my brother's teacher? Black undergraduates, racial socialization, and peer pedagogies in predominantly white postsecondary contexts. Review of Research in Education, 37(1), 183-211. https:// doi.org/10.3102/0091732X12471300

Harper, S. R. (2018). Black male studentathletes and racial inequities in NCAA Division I revenue-generating college sports: 2018 edition.

Harper, S. R., \& Nichols, A. H. (2008). Are they not all the same?: Racial heterogeneity among Black male undergraduates. Journal of College Student Development, 49(3), 199-214. https://doi.org/10.1353/csd.0.0003

Harris, P. C. (2014). Do team sports matter for Black males? Journal for the Study of Sports and Athletes in Education, 8(3), 137-147. https://doi.org/10.117 9/1935739714z.00000000027

Harris, P. C., Hines, E. M., Mayes, R. D., Thomas, A., \& Bagley, B. (2015). Balancing academics and athletics in high school: A phenomenological study of three Black male student athletes. Journal for the Study of Sports and Athletes in Education, 9(3), 172189. https://doi.org/10.1080/193573 97.2015.1123001

Harrison, C. K., Comeaux, E., \& Plecha, M. (2006). Faculty and male football and basketball players on university campuses: An empirical investigation of the "intellectual" as mentor to the student athlete. Research Quarterly for Exercise and Sport, 77(2), 277-284. https://doi.org/10.1080/02701367.2 006.10599361

Harrison Jr., L., Bimper Jr., A. Y., Smith, M. P., \& Logan, A. D. (2017). The mis-education of the African American student-athlete. Kinesiology Review, 6(1), 60-69.

Harrison Jr., L., Harrison, C. K., \& Moore, L. N. (2002). African American racial identity and sport. Sport, Education, and Society, 7(2), 121-133. https://doi. org/10.1080/1357332022000018823 Harrison Jr., L., Sailes, G. A., Rotich, W. K., \& Bimper Jr., A. Y. (2011). Living the dream or awakening from the nightmare: Race and athletic identity. Race Ethnicity and Education, 14(1), 91-103. https://doi.org/10.1080/136 13324.2011.531982

Hawkins, B. J. (2010). The new plantation: Black atblete, college sports, and predominantly white NCAA institutions. Palgrave Macmillan. https://doi.org/10.1017/ CBO9781107415324.004

Henry, W. J., \& Closson, R. B. (2012). The racial identity development 
of male student-athletes when

blacks are the majority and whites are the minority. Journal of Student Affairs Research and Practice, 49(1), 17-32. https://doi.org/10.1515/ jsarp-2012-6285

Hodge, S. R., Burden, J. W., Robinson, L. E., \& Bennett, R. A. (2008). Theorizing on the stereotyping of Black male student-athletes. Journal for the Study of Sports and Atbletes in Education, 2(2), 203-226.

Hodge, S. R., Harrison Jr., L., Burden, J. W., \& Dixson, A. D. (2008).

Brown in black and white-then and now: A question of educating or sporting African American males in America. American Behavioral Scientist, 51(7), 928-952. https://doi. org/10.1177/0002764207311998

Houle, J. L. W., \& Kluck, A. S. (2015). An examination of the relationship between athletic identity and career maturity in student-athletes. Journal of Clinical Sport Psychology, 9(1), 24-40. https://doi.org/10.1123/jcsp.20140027

Jones, S. R., \& McEwen, M. K. (2000). A conceptual model of multiple dimensions of identity. Journal of College Student Development, 41(4), 405414.

Kelly, D. D. (2009). Paying the price for "slow integration": A bistory of race and football at the University of Texas at Austin from 1954-1972. The University of Texas at Austin.

Kelly, D. D., \& Dixon, M. A. (2014). Successfully navigating life transitions among African American male student-athletes: A review and examination of constellation mentoring as a promising strategy. Journal of Sport Management, 28(5), 498-514.

Killeya-Jones, L. A. (2005). Identity structure, role discrepancy and psychological adjustment in male college student-athletes. Journal of Sport Behavior, 28(2), 167-186.

Lanter, J. R., \& Hawkins, B. J. (2013). The Economic Model of Intercollegiate Athletics and Its Effects on the College Athlete Educational Experience. Journal of Intercollegiate Sport, 6(1), 86.

Lapchick, R. E. (2019a). The 2019 racial and gender report card: National Basketball Association.

Lapchick, R. E. (2019b). The 2019 racial and gender report card: National Football League.

Lu, L. Di, Heinze, K. L., \& Soderstrom, S. (2018). Playing multiple positions: Student-athlete identity salience and conflict. Journal of Intercollegiate Sport, 11(2), 214-241. https://doi. org/10.1123/jis.2018-0034

Melendez, M. C. (2006). The influence of athletic participation on the college adjustment of freshmen and sophomore student athletes. Journal of College Student Retention: Research, Theory \& Practice, 8(1), 39-55. https://doi. org/10.2190/8gly-g974-v7fm-e1yd Melendez, M. C. (2008). Black football players on a predominantly white college campus: Psychosocial 
and emotional realities of the Black college athlete experience. Journal of Black Psychology, 34(4), 423-451. https://doi. org/10.1177/0095798408319874

Melendez, M. C. (2009). Pyschosocial influences on college adjustment in Division I student-athletes: The role of athletic identity. Journal of College Student Retention, 11(3), 345-361. https://doi.org/10.2190/CS.11.3.c

Miller, P. S., \& Kerr, G. A. (2003). The role experimentation of intercollegiate student athletes. Sport Psychologist, 17(2), 196-219.

Murdock, J. L., Strear, M. M., JenkinsGuarnieri, M. A., \& Henderson, A. C. (2016). Collegiate athletes and career identity. Sport, Education and Society, 21(3), 396-410. https://doi.org/10.10 80/13573322.2014.924920

NCAA. (2020a). Division I graduation rates database. NCAA.Org. http://www. ncaa.org/about/resources/research/ division-i-graduation-rates-database NCAA. (2020b). NCAA demographics database. NCAA.Org. http://www. ncaa.org/about/resources/research/ ncaa-demographics-database

Oseguera, L. (2010). Success despite the image: How African American male student-athletes endure their academic journey amidst negative characterizations. Journal for the Study of Sports and Athletes in Education, 4(3), 297-324. https://doi.org/10.1179/ ssa.2010.4.3.297

Parsons, J. (2013). Student athlete perceptions of academic success and athlete stereotypes on campus. Journal of Sport Behavior, 36(4), 400-416. Porter, J. (2019). An examination of the experiences of Black football athletes. Journal of Intercollegiate Sport, 12(1), 73-102. https://doi.org/10.17161/jis. v12i1.11561

Rubin, L. M. (2016). The detrimental effects of big-time college sports on Black student-athletes' academic success. Journal for the Study of Sports and Athletes in Education, 10(3), 185198. https://doi.org/10.1080/193573 97.2016.1258966

Rubin, L. M., \& Rosser, V. J. (2014). Comparing Division IA scholarship and non-scholarship student-athletes: A discriminant analysis. Journal of Issues in Intercollegiate Athletics, 7, 43-64.

Sailes, G. A. (1993). An investigation of campus stereotypes: The myth of Black athletic superiority and the dumb jock stereotype. Sociology of Sport Journal, 10(1), 88-97.

Sailes, G. A. (2002). African-American college athletes: Debunking the myth of the dumb jock. The Journal of Blacks in Higher Education, 35, 36-40. Sanders, J. P., \& Hildenbrand, K. (2010). Major concerns? A longitudinal analysis of student-athletes' academic majors in comparative perspective. Journal of Intercollegiate Sport, 3(2), 213-233. https://doi.org/10.1021/ om010914+

Schneider, R. G., Ross, S. R., \& Fisher, M. (2010). Academic clustering and major selection of intercollegiate 
student-athletes. College Student Journal, 44(1), 64-71.

Simien, E. M., Arinze, N., \& McGarry, J. (2019). A portrait of marginality in sport and education: Toward a theory of Intersectionality and racedgendered experiences for Black female college athletes. Journal of Women, Politics \& Policy, 40(3), 409_ 427. https://doi.org/10.1080/155447 7X.2019.1614865

Simiyu, W. W. N. (2012). Challenges of being a Black student athlete on U.S. college campuses. Journal of Issues in Intercollegiate Athletics, 5, 40-63.

Simons, H. D., Bosworth, C., Fujita, S., \& Jensen, M. (2007). The athlete stigma in higher education. College Student Journal, 41(2), 251-273.

Singer, J. N. (2005). Understanding racism through the eyes of African American male studentathletes. Race Ethnicity and Education, 8(4), 365-386. https://doi. org/10.1080/13613320500323963

Singer, J. N. (2008). Benefits and detriments of African American male athletes' participation in a big-time college football program. International Review for the Sociology of Sport, 43(4), 399-408. https:/ / doi. org/10.1177/1012690208099874

Singer, J. N. (2016). African American male college athletes' narratives on education and racism. Urban Education, 51(9), 1065-1095. https:/ / doi.org/10.1177/0042085916669749

Singer, J. N. (2019). Race, sports, and education: Improving opportunities and outcomes for Black male college athletes. Harvard Education Press. Singer, J. N., \& May, R. A. B. (2011). The career trajectory of a black male high school basketball player: A social reproduction perspective. International Review for the Sociology of Sport, 46(3), 299-314. https://doi. org/10.1177/1012690210378283

Steele, C. M., \& Aronson, J. M. (1995). Stereotype threat and the intellectual test performance of African Americans. Journal of Personality and Social Psychology, 69(5), 797-811. https://doi.org/10.1037/00223514.69.5.797

Steinfeldt, J. A., Reed, C., \& Steinfeldt, M. C. (2010). Racial and athletic identity of African American football players at historically Black colleges and universities and predominantly White institutions. Journal of Black Psychology, 36(1), 3-24. https://doi. org/10.1177/0095798409353894

Stone, J., Harrison, C. K., \& Mottley, J. (2012). "Don't call me a studentathlete": The effect of identity priming on stereotype threat for academically engaged African American college athletes. Basic and Applied Social Psychology, 34(2), 99-106. https://doi.org/10.1080/01973533.2 012.655624

Tinto, V. (1993). Leaving college: Rethinking the causes and cures ofstudent attrition (2nd ed.). University of Chicago Press. Van Rheenen, D. (2013). Exploitation in college sports: Race, revenue, and educational reward. International 
Review for the Sociology of Sport, 48(5), 550-571. https://doi. org/10.1177/1012690212450218 Wininger, S. R., \& White, T. A. (2015). An examination of the dumb jock stereotype in collegiate studentathletes: A comparison of student versus student-athlete perceptions. Journal for the Study of Sports and
Athletes in Education, 9(2), 75-85. https://doi.org/10.1179/193573971 5z.00000000036

Zeiser, K. L. (2011). Examining racial differences in the effect of popular sports participation on academic achievement. Social Science Research, 40(4), 1142-1169. https://doi. org/10.1016/j.ssresearch.2011.03.002 